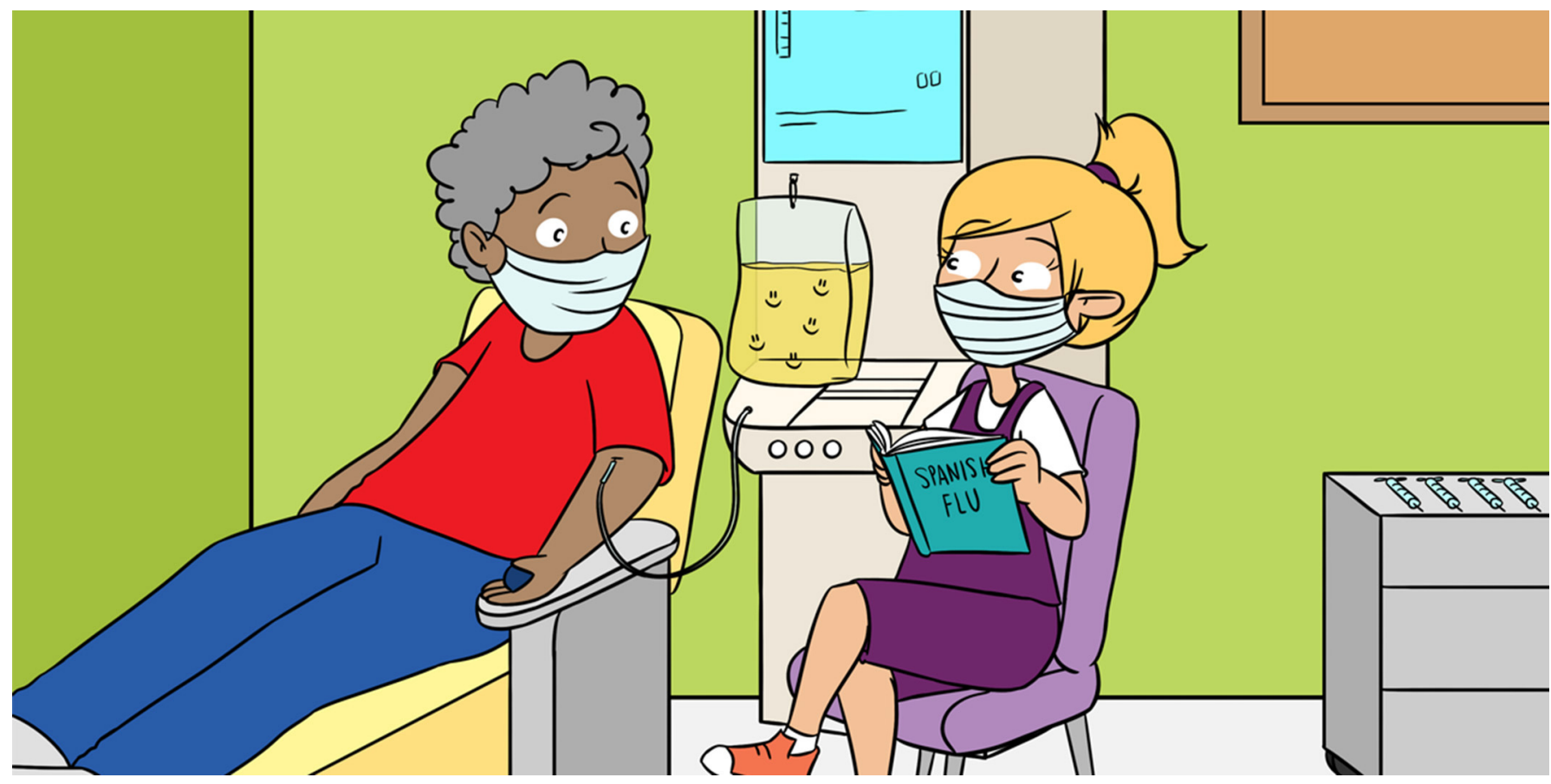

\title{
COVID-19: FIGHTING A VIRUS GONE VIRAL
}

\section{Daniel Montelongo-Jauregui ${ }^{1 *}$, Ahmed S. Sultan ${ }^{1}$, Taissa Vila ${ }^{1}$ and Mary Ann Jabra-Rizk ${ }^{1,2}$}

${ }^{1}$ Department of Oncology and Diagnostic Sciences, School of Dentistry, University of Maryland, Baltimore, Baltimore, MD, United States

${ }^{2}$ Department of Microbiology and Immunology, School of Medicine, University of Maryland, Baltimore, Baltimore, MD, United States

\section{YOUNG REVIEWERS:}

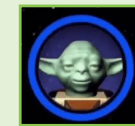

NOAH

AGE: 15

SAHASRA

AGE: 14
COVID-19 is the disease caused by the new coronavirus SARS-CoV-2. It has caused a lot of suffering and devastation around the globe. No vaccines or medications are available to treat this disease to date. In this article, we describe the mysterious emergence of this virus and explain how a virus that only infects animals begins to infect humans. Additionally, as this new virus continues to spread around the world, scientists are turning to an old medical remedy to help sick people. This therapy involves harvesting antibodies from the blood of people who have recovered from COVID-19 and passing these antibodies to people to protect them from getting the infection, or to treat them if they are sick. While scientists are earnestly working on developing a vaccine, could this old-fashioned technique buy us the time needed to develop new treatments?

In 1918, the Spanish Flu, an outbreak caused by an influenza virus infected one-third of the world's population. Fortunately, the world has not witnessed a pandemic of such proportions since then ... until 
PANDEMIC

An outbreak that affects large populations, such as multiple countries or continents.

\section{PATHOGEN}

An organism that can cause disease in a host.

\section{ZOONOTIC}

SPILLOVER

Term to describe the phenomenon where a pathogen that only affected a particular species of animals (bats) can infect humans. Mostly as a consequence of close inter-species interactions.

\section{MORTALITY RATE}

Represents the number of deaths in a particular location in a given time. now! COVID-19 is a respiratory disease that mysteriously emerged in December 2019 and has been wreaking havoc around the world. This devastating disease is caused by a coronavirus, the same class of virus that causes the common cold. But this new virus, named SARS-CoV-2, is not your typical coronavirus. In fact, at the time of writing this article, more than 11 million people have been infected worldwide, and more than 526,000 people have died. Can you believe that this devastation is caused by life's smallest creature? The world stands helpless, unable to fully control the virus's spread, despite all the scientific and medical advances we have made.

\section{VIRUSES CAN MOVE FROM ANIMALS INTO PEOPLE}

In December 2019, several patients in Wuhan, China were reported to be suffering from unknown viral pneumonia. Soon after, more patients in that city were diagnosed with the same disease. On January 9, scientists identified a new virus as the cause of the mysterious disease [1]. They found that the new virus belongs to a class of viruses called coronavirus, and so they named it SARS-CoV-2 [1]. The name comes from the disease it causes: severe acute respiratory syndrome; CoV stands for coronavirus, and the number $\mathbf{2}$ was added because it is the second coronavirus that causes a serious respiratory disease [1].

Next, scientists examined the DNA of the virus they recovered from a sick person and the results were surprising. They discovered that the new virus infecting humans is very similar to a coronavirus found in bats (96\% similarity) [2]. This outcome led them to think that the virus must have jumped from bats to humans [1]. But did SARS-CoV-2 jump directly from bats to humans? Or did it first infect an intermediate animal before it got to humans? So far, these questions remain unanswered, but scientists seem to agree that SARS-CoV-2 jumped from an animal to humans. The phenomenon in which a pathogen jumps between species (like from animals to humans) is known as zoonotic spillover [3, 4].

SARS-CoV-2 is not the first example of zoonotic spillover to cause problems for humans. In 2002, a virus called severe acute respiratory syndrome coronavirus (SARS-CoV) emerged as a pathogen. Interestingly, it was also found to have jumped to humans from bats. In just a few months, the virus infected over 8,000 people and killed roughly $10 \%$ of those infected [1]. However, by 2003, SARS-CoV suddenly disappeared. By 2012, another coronavirus emerged: Middle East respiratory syndrome coronavirus (MERS-CoV). MERS-CoV was also a result of zoonotic spillover from bats [1]. Fortunately, MERS-CoV did not spread around the world, mostly because the virus was not highly infectious. On the other hand, the MERS-CoV mortality rate of around $35 \%$ makes it one of the deadliest pathogens to date. 
IMMUNE SYSTEM

A complex group of host cells and cell-forming tissues that orchestrate defense mechanisms against foreign pathogens to prevent and combat disease.

\section{VACCINE}

Substance designed to stimulate the immune system to protect against pathogens. It is generally made with a killed pathogen (or its components) to induce production of antibodies against that specific pathogen
As of now, the mortality rate for COVID-19 is low ( 4\%). In contrast to the previous epidemics, SARS-CoV-2 is extremely efficient at spreading among people. The virus can survive for hours on surfaces, and this allows for a high level of transmission. Most concerning is the recent realization that most people who are infected do not feel sick for a long time, so they are not aware they are infected. When they are still feeling ok, they could be spreading the virus to others. Since SARS-CoV-2 is essentially new to humans, we do not have baseline defenses in place to rapidly and efficiently combat the virus upon infection. Put together, these factors made a recipe for a world-shattering pandemic of massive proportions.

\section{DO NOT BLAME THE BATS}

Scientists agree that although bats are the likely source of coronaviruses, the spillover from bats is the result of human activity. How? Well, when bats are hunted, their immune system gets stressed and allows the viruses that live in them to increase in number and spillover into the environment [5]. Another point is that when humans are sick and have fever, most viruses do not survive because they cannot tolerate high temperature. But when bats fly, their body temperature goes up, and so viruses that live in them have to adapt to tolerate higher temperatures. As a result, when these viruses infect humans, they can now survive and cause disease [5].

\section{HOW DO WE STOP A PANDEMIC?}

Stopping the spread of an efficient virus is close to impossible. The most effective way to protect people against infection is through vaccination. When you are infected with a pathogen, your immune system is alerted to the presence of a foreign invader. In response, your white blood cells produce molecules called antibodies. These antibodies can neutralize the pathogen and help your body to eliminate it. Fortunately, once produced, antibodies usually stay with us for a long time. So, if your antibodies see the same pathogen again, they will quickly neutralize it before it makes you sick.

Learning how the immune system works has led to the development of vaccines. How so? Well, a vaccine is basically a formulation made from a pathogen that was rendered harmless. Sometimes vaccines are made with a small piece of the pathogen. Even if the pathogen is harmless, the immune system perceives the pathogen in the vaccine as a threat and makes antibodies against it. Therefore, vaccination is a clever strategy to trick the immune system into producing antibodies that can protect us if we encounter the real pathogen. Researchers all over the world are intensely working on developing vaccines against COVID-19, but this work takes a lot of time. In the meantime, scientists have been trying to find a way to help COVID-19-infected patients. 
CONVALESCENT

PLASMA THERAPY

Medical treatment against pathogens that consists of the transfer of antibodies from the blood plasma of a convalescent (recovered) individual to an ill individual. It has the purpose of transferring immune protection against pathogens
Luckily for us, they have found an old technique that was used in previous pandemics. Could this old-fashioned therapy buy us time until we develop a vaccine?

\section{FIGHTING COVID-19 WITH THE HELP OF RECOVERED PATIENTS}

Have you ever heard of convalescent plasma therapy? It is a kind of treatment that was used during the previously discussed Spanish Flu pandemic. More recently, it was successfully used during the 2009-2010 H1N1 influenza virus pandemic, as well as the in the Ebola epidemic of 2013 [1]. Simply put, it is the transfer of blood plasma from someone with antibodies against a pathogen into other people, in order to protect them from infection with that pathogen [6]. The antibodies our bodies make are present in the plasma component of the blood. So, if you get plasma from a person who was infected with the virus, that plasma is likely to already contain antibodies against that specific virus. This plasma is called "convalescent" because it is taken from recovered (convalescent) patients. Thus, when you give convalescent plasma to a sick person, that person will be getting antibodies that are ready to go fight the virus. Typically, takes weeks for people to produce their own antibodies after they are infected. In the meantime, the virus can replicate, making patients more and more ill. Therefore, giving plasma with antibodies made by another person could save the lives of patients.

A good thing about COVID-19 is that, according to the data, most infected people can recover from it. It is likely that people who recover become immune to the virus, thanks to the antibodies they produced that remain in their blood plasma [6]. Plasma harvested from convalescent COVID-19 patients, containing antibodies against SARS-CoV-2, can be used in two ways, as illustrated in Figure 1. The antibody-containing plasma could be used for prevention, which means giving high-risk people plasma before they get infected, to protect them from getting COVID-19. Moreover, the plasma could be used to treat patients who are already infected but are not fighting the virus well.

\section{WHAT HAVE WE LEARNED?}

Recently, we have witnessed the emergence of three coronaviruses that have caused significant mortality in humans. Sadly, one thing is for certain: SARS-CoV-2 will not be the last. Therefore, we need to increase surveillance of viruses in animals, which will helpful us understand what causes zoonotic spillovers and how to prevent them. As the COVID-19 pandemic expands, the big question is, can we develop a vaccine soon to stop this pandemic? 
Figure 1

Convalescent plasma therapy. Person \#1 represents a patient who gets infected with SARS-CoV-2. Upon infection, Person \#1 produces specific antibodies (blue "Y"s) that neutralize the virus. Once recovered, the antibodies remain in the blood plasma. These antibodies can be used for two therapeutic purposes: prevention (see Person \#2) and treatment (see Person \#3). Person \#2 represents someone who is highly susceptible to infection. Using antibodies from Person \#1, Person \#2 acquires immunity. Person \#3 represents a patient who is ill with the virus. Antibodies from Person \#1 help Person \#3 to clear infection.

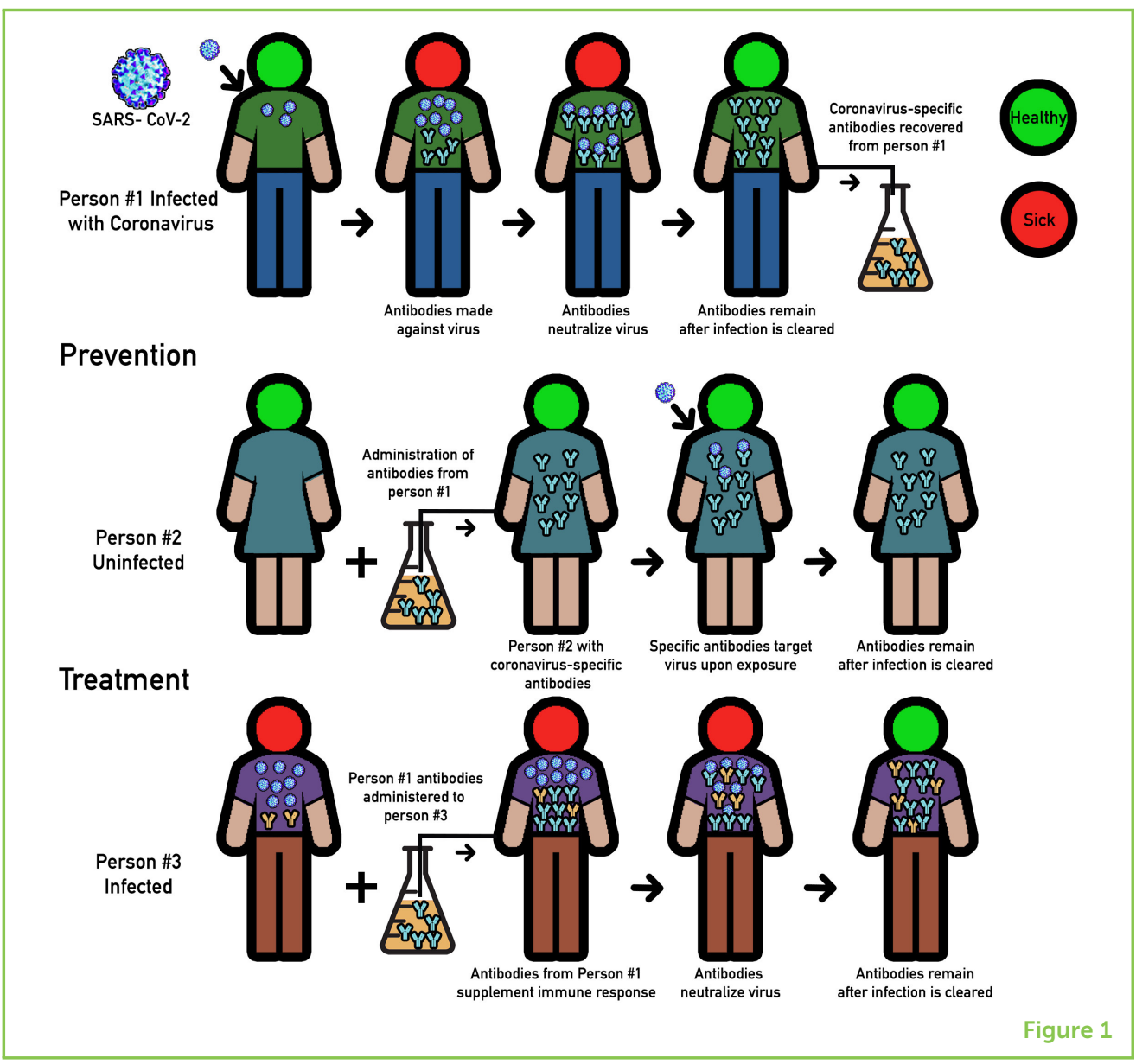

It is unlikely that a successful vaccine will become available very soon; fortunately however, transferring antibodies from recovered patients to those at risk can save lives. In fact, convalescent plasma therapy against COVID-19 is now being tested as a way to treat very ill patients, with promising results $[7,8]$. The other important questions we should be asking are can we learn what caused the pandemic? Could we use this knowledge to prevent future pandemics? And will we be better prepared to deal with the next pandemic? Most importantly, humans should consider this pandemic as a warning that damaging our environment, and destroying natural habitats of animals like bats, can also endanger human life.

\section{REFERENCES}

1. Weston, S., and Frieman, M. B. 2020. COVID-19: knowns, unknowns, and questions. mSphere 5:e00203-20. doi: 10.1128/mSphere.00203-20

2. Malik, Y. S., Sircar, S., Bhat, S., Sharun, K., Dhama, K., Dadar, M., et al. 2020. Emerging novel coronavirus (2019-nCoV)-current scenario, evolutionary perspective based on genome analysis and recent developments. Vet. Q. 40:68-76. doi: 10.1080/01652176.2020.1727993 
3. Rodriguez-Morales, A. J., Bonilla-Aldana, D. K., Balbin-Ramon, G. J., Rabaan, A. A., Sah, R., Paniz-Mondolfi, A., et al. 2020. History is repeating itself: Probable zoonotic spillover as the cause of the 2019 novel coronavirus epidemic. Infez. Med. 28:3-5. Available online at: https://www.infezmed.it/media/journal Nol_28_1_2020_1.pdf

4. Plowright, R. K., Parrish, C. R., McCallum, H., Hudson, P. J., Ko, A. I., Graham, A. L., et al. 2017. Pathways to zoonotic spillover. Nat. Rev. Microbiol. 15:502-10. doi: $10.1038 /$ nrmicro.2017.45

5. Wang, L. F., and Anderson, D. E. 2019. Viruses in bats and potential spillover to animals and humans. Curr. Opin. Virol. 34:79-89. doi: 10.1016/j.coviro.2018. 12.007

6. Casadevall, A., and Pirofski, L. 2020. The convalescent sera option for containing COVID-19. J. Clin. Invest. 130:1545-8. doi: 10.1172/jci138003

7. Joyner, M., Wright, R. S., Fairweather, D., Senefeld, J., Bruno, K., Klassen, S., et al. 2020. Early safety indicators of COVID-19 convalescent plasma in 5,000 patients. medRxiv. doi: 10.1172/JCl140200

8. Montelongo-Jauregui, D., Vila, T., Sultan, A. S., and Jabra-Rizk, M. A. in press. Convalescent serum therapy for COVID-19: a 19th century remedy for a 21st century disease. PLOS Pathog.

SUBMITTED: 14 April 2020; ACCEPTED: 06 July 2020;

PUBLISHED ONLINE: 22 July 2020.

EDITED BY: Michel Goldman, Institute for Interdisciplinary Innovation in Healthcare (I3h), Belgium

CITATION: Montelongo-Jauregui D, Sultan AS, Vila T and Jabra-Rizk MA (2020) COVID-19: Fighting a Virus Gone Viral. Front. Young Minds 8:100. doi: 10.3389/ frym.2020.00100

CONFLICT OF INTEREST: The authors declare that the research was conducted in the absence of any commercial or financial relationships that could be construed as a potential conflict of interest.

COPYRIGHT (c) 2020 Montelongo-Jauregui, Sultan, Vila and Jabra-Rizk. This is an open-access article distributed under the terms of the Creative Commons Attribution License (CC BY). The use, distribution or reproduction in other forums is permitted, provided the original author(s) and the copyright owner(s) are credited and that the original publication in this journal is cited, in accordance with accepted academic practice. No use, distribution or reproduction is permitted which does not comply with these terms.

\section{YOUNG REVIEWERS}

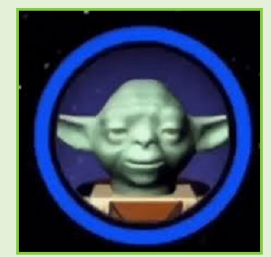

\section{NOAH, AGE: 15}

My favorite subjects at school are physics - particularly nuclear physics - and drama. Outside of school, I play guitar and have an unhealthy obsession with Green Day. After school, I would love to be an actor or nuclear physicist. I have a weird sense of humor and therefore apologize in advance if you ever meet me. 


\section{SAHASRA, AGE: 14}

Hello, I am Sahasra, rising tenth grader. I am eagerly waiting to start my high school. I am interested in Science and Language. I love listening to music and reading books. J. K. Rowling is my hero. Playing volleyball is my passion. I play for my school and local club. I would love to pursue my career in life sciences/healthcare.

\section{AUTHORS}

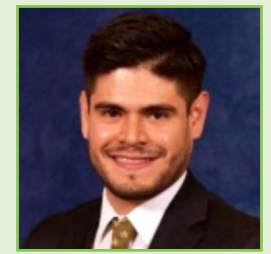

\section{DANIEL MONTELONGO-JAUREGUI}

I am a researcher in the field of Microbiology and Immunology at the University of Maryland, Baltimore. I study how pathogens make us ill with the goal of identifying new therapies. Aside from the lab, I love playing sports, riding my bike and listening to music. *dmontelongo@aumaryland.edu; orcid.org/0000-0001-6079-4277
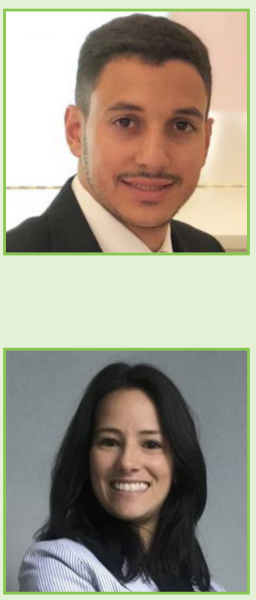

\section{AHMED S. SULTAN}

I am a Clinical Assistant Professor at the University of Maryland, Baltimore and I am a specialist in the fields of Oral Medicine and Oral Pathology. I am also a research scientist and my work is focused on understanding infections of the mouth and how to treat them. I enjoy fishing and my friends consider me an up-and-coming food critic! orcid.org/0000-0001-5286-4562

\section{TAISSA VILA}

I am a senior research scientist in Microbiology and Immunology at the University of Maryland, Baltimore. My research aims to understand why infections caused by multiple pathogens are more serious and difficult to treat than those caused by only one infectious agent. I am also a coffee lover and in my free time I enjoy reading. orcid.org/0000-0001-5600-4367

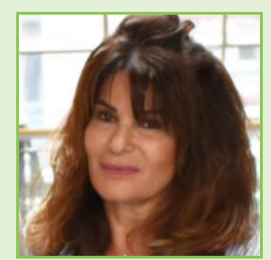

\section{MARY ANN JABRA-RIZK}

I am a Professor of Microbiology and Immunology at the University of Maryland, Baltimore. My research focuses on understanding the host-pathogen interactions that influence the development of infectious diseases. When not doing science, I enjoy reading, gardening, knitting, and watching movies. orcid.org/0000-0002-4425-3873 